УДК 621.822.681.2:369.64

DOI 10.36910/6775-2313-5352-2021-18-13

${ }^{1}$ Марчук В.I., ${ }^{1}$ Марчук І.В., ${ }^{2}$ Джугурян Т.Г., ${ }^{1}$ Карпюк В.О.

Луцький національний технічний університет, м. Луцьк, Україна

Щецінська морська академія, Польща

\title{
ПРО ДОЦІЛЬНІСТЬ ЗАСТОСУВАННЯ ШЛІФУВАЛЬНИХ КРУГІВ 3 ПЕРЕРИВЧАСТИМ ПРОФІЛЕМ НА ОПЕРАЦІЯХ БЕЗЦЕТРОВОГО ШЛІФУВАННЯ ПОВЕРХОНЬ ОБЕРТАННЯ
}

В роботі зроблено порівняльний аналіз роботи шліфувальних кругів з суцільною $i$ переривчастою робочою поверхнею для фінішної абразивної обробки поверхонь кілець роликопідшипників. Для фінішної абразивної обробки поверхонь кілець роликопідиипників показано, щцо результати очікуваної контактної температури, шорсткості і інтенсивності зношування при заданій інтенсивності знімання металу підтверджуються теоретичними розрахунками. Одержані результати дають змогу зробити висновок, що на операиіях безцентрового шліфування, особливо при обробці кілець роликопідщипників, доцільно використовувати шліфувальні круги з переривчастою поверхнею.

Ключові слова: шліфувальний круг, абразивний інструмент, безиентрове шліфування, переривчастий профіль, розмірне зночення, температура в зоні різання, поверхні обертання.

Постановка проблеми. 3 метою підвищення показників якості та стабілізації параметрів точності деталей підшипників у сучасному машинобудуванні використовуються прогресивні методи механообробки такі, як шліфування кругами 3 переривчастим профілем. Найрозповсюдженішими представниками таких деталей в підшипниковому виробництві $\epsilon$ внутрішні та зовнішні кільця підшипників. Застосування переривчастого шліфувальня дозволяє зменшити температуру в зоні шліфування на 15 - $25 \%$ та підвищити ефективність фінішних шліфувальних операцій. Однак цей спосіб шліфування супроводжується складними динамічними процесами, що пов'язані $з$ можливим виникненням дисбалансу шліфувальних кругів.

Основне завдання та одержані результати роботи. Метою дослідження $є$ зробити порівняльний аналіз i теоретичну перевірку ефекту роботи шліфувальних кругів 3 переривчастим та суцільним профілем та на операціях безцентрового шліфування.

Згідно [1] застосування на операціях шліфування абразивного інструменту 3 переривчастим профілем дозволяє вдосконалити режими обробки при забезпеченні необхідних фізико-механічних властивостей оброблюваної поверхні. За рахунок періодичного переривання процесу різання температура в зоні контакту абразивної поверхні 3 матеріалом деталі зменшується і одночасно в технологічній системі збуджуються високочастотні коливання, зменшуючи енергоємність усього процесу оброблення в результаті дослідження.

Як показано в результатах [2-4], при шліфуванні абразивним інструментом 3 переривчастою робочою поверхнею присутнє поєднання ефекту від періодичного переривання процесу різання (в зоні контакту абразивних зерен з матеріалом деталі температура не досягає квазістаціонарного стану) з ефектом сталого загострення рельєфу круга надає змогу зменшення теплонапруженності процесу оброблення. Математична модель процесу шліфування поверхонь кругом з переривчастим профілем і розрахункові дані ії залежності наводяться в [1].

Для перевірки запропонованих методик розрахунку параметрів абразивного інструменту 3 переривчастою робочою поверхнею і режимів оброблення виконані розрахунки і побудовані графіки залежності: очікуваної контактної температури, шорсткості і інтенсивності зносу від заданої інтенсивності знімання металу (рис.1) [4].

Розрахунки проводилися для шліфування заготовки із гартованої сталі X12Ф1 (HRC 60 ... 64). Порівнянні види інструменту: шліфувальний круг з суцільною робочою поверхнею тип 1 $300 x 40 x 127$ 25AF40LV i шліфувальний круг 3 переривчастою робочою поверхнею тип 1 $300 x 40 x 127$ 25AF40LV (10 пазів завдовжки $l_{1}=l_{2}=47$ мм які розташовані під кутом до вісі кола $\left.\alpha=15^{\circ}\right)$. Прийняті вихідні дані: діаметр шліфувального круга, $\mathrm{D}=0,30$ м; площа оброблюваної поверхні $F_{3 a z}=8 \cdot 10^{-3} \cdot \mu^{2}$; глибина різання $t=0.02 \mathrm{мм} /$ дв.хід; коефіцієнт температуропровідності $3 \cdot 10^{6} \cdot \mathrm{s}^{2} / c$; коефіцієнт теплопровідності $\lambda=16,7 \mathrm{BT} /\left({ }^{\circ} \mathrm{C} \cdot m^{2}\right)$; радіус 
заокруглення абразивного зерна $\rho_{g}=1.45^{\cdot} \cdot 10^{-5} \mathrm{M}$; коефіцієнт стружко утворення $K_{c}=0,9$; швидкість заготовки $V_{u}=0.1 \mathrm{~m} / \mathrm{c} ; V_{k}-$ швидкість круга, $35 \mathrm{~m} / \mathrm{c}$; зернистість круга, $\bar{x}=40$ мкм; $n_{g}$ - середня кількість вершин зерен на одиницю поверхні робочого шару, $\eta=0,3 ; m$ - об'ємна концентрація зерен круга, $m=0,5$;
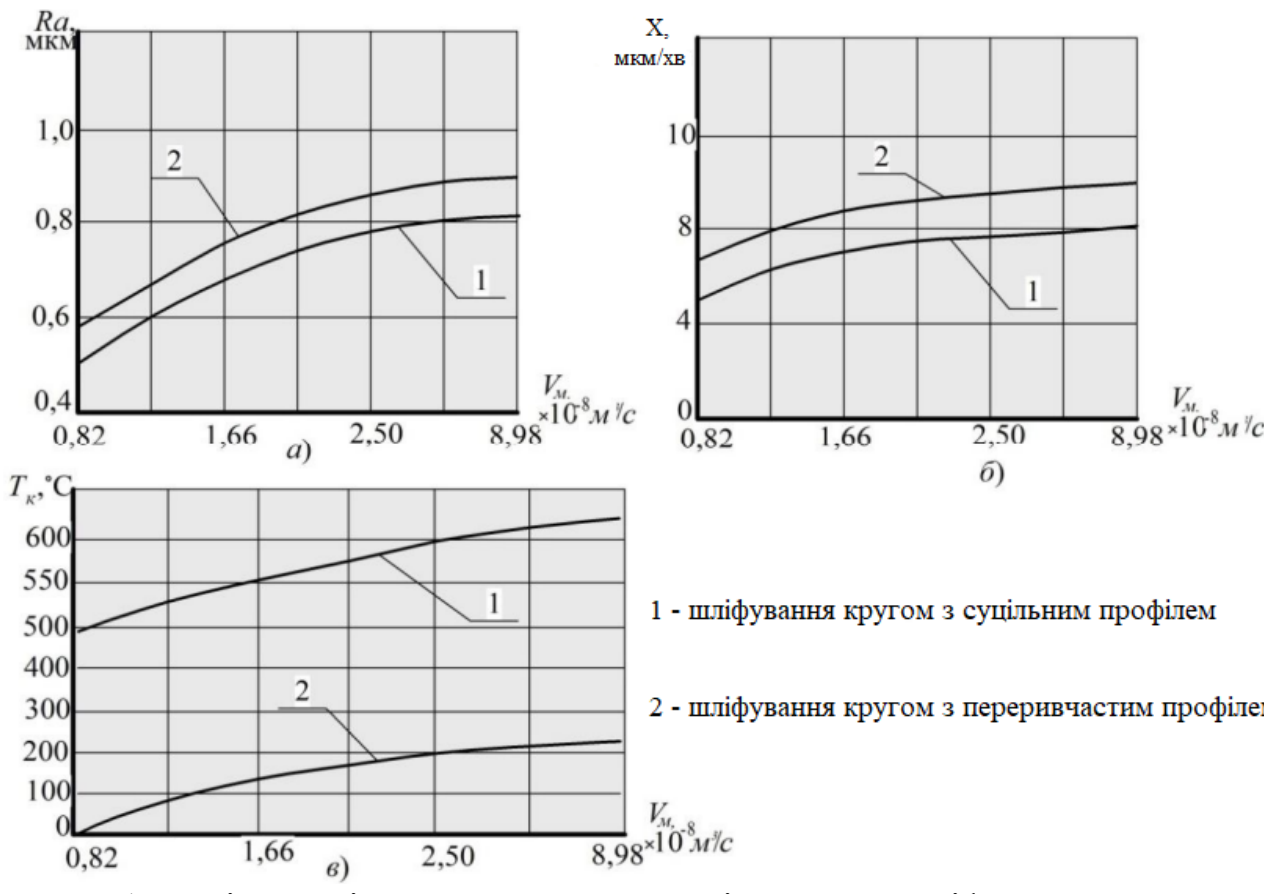

б)

1 - шліфування кругом з суцільним профілем

2 - шліфування кругом $з$ переривчастим профілем $V_{M-1}^{-8}$
$\times 10^{-8} M^{\prime} C$

Рис. 1. Порівняльні результати розрахунків процесу шліфування кругами з суцільною (1) та $з$ переривчастою (2) робочою поверхнею від заданої інтенсивності знімання металу: $a-$ шорсткість поверхні; $\sigma$ - інтенсивність зносу; в - контактна температура.

Розрахунки проводилися для шліфування заготовки із гартованої сталі X12Ф1 (HRC 60 ... 64). Порівнянні види інструменту: шліфувальний круг з суцільною робочою поверхнею тип 1 $300 x 40 x 127$ 25AF40LV i шліфувальний круг 3 переривчастою робочою поверхнею тип 1 300x40x127 25AF40LV (10 пазів завдовжки $l_{1}=l_{2}=47$ мм які розташовані під кутом до вісі кола $\alpha=15^{\circ}$ ). Прийняті вихідні дані: діаметр шліфувального круга, $\mathrm{D}=0,30$ м; площа оброблюваної поверхні $F_{3 a z}=8 \cdot 10^{-3} \cdot \mu^{2}$; глибина різання $t=0.02 \mathrm{мм} /$ дв.хід; коефіцієнт температуропровідності $3 \cdot 10^{6} \cdot \mathrm{M}^{2} / c$; коефіцієнт теплопровідності $\lambda=16,7 \mathrm{BT} /\left({ }^{\circ} \mathrm{C} \cdot M^{2}\right)$; радіус заокруглення абразивного зерна $\rho_{g}=1.45 \cdot 10^{-5}$, ; коефіцієнт стружко утворення $K_{c}=0,9$; швидкість заготовки $V_{u}=0.1 \mathrm{~m} / c ; V_{k}-$ швидкість круга, $35 \mathrm{M} / \mathrm{c}$; зернистість круга, $\bar{x}=40$ мкм; $n_{g}-$ середня кількість вершин зерен на одиницю поверхні робочого шару, $\eta=0,3 ; m-$ об'ємна концентрація зерен круга, $m=0,5$;

Необхідно визначити: шорсткість обробленої поверхні, розмірне зношення кола в одиницю часу, контактну температуру і інтенсивність знімання металу. Нижче наведені приклади виконання розрахунків зазначених характеристик. $[3,5]$

Фактична глибина різання:

$$
\begin{array}{r}
t_{f}=\sqrt{\frac{D^{2}}{2}-\left(\sqrt{D \cdot t}-\frac{V_{u}}{V_{k}}\left(l_{1}+l_{2}\right)\right)^{2}}-\left(\sqrt{\frac{D^{2}}{2}-D \cdot t}\right) \\
=\sqrt{0.5 \cdot 0.3^{2}-\left(\sqrt{0.3 \cdot 0.02 \cdot 10^{-3}}-\frac{0.1}{35} \cdot(0.04+0.0255)\right)^{2}}- \\
-\sqrt{0.5 \cdot 0.3^{2}-0.25 \cdot 0.02 \cdot 10^{-3}}=5.24 \cdot 10^{-6} \mathrm{M} .
\end{array}
$$


Очікуване середньоарифметичне значення відхилення профілю і швидкості зносу круга вираховуємо за формулами $[3,5]$ :

$$
\begin{aligned}
& R_{a}=\frac{0,25 \cdot V_{u}^{0.4} \cdot\left(\sqrt{\frac{D^{2}}{2}-\left((\sqrt{D t})-\frac{V_{u}}{V_{k}}\left(l_{1}+l_{2}\right)\right)^{2}}-\left(\sqrt{\frac{D^{2}}{2}-D t}\right)\right)^{0.6}}{K_{c}^{0.6} \cdot\left(V_{k} \pm V_{u}\right)^{0.4} \cdot n_{g}^{0.4} \cdot D^{0.2} \cdot \rho_{g}^{0.2}} \\
& =\frac{0.25 \cdot 0.1^{0.4} \cdot\left(5.24 \cdot 10^{-6}\right)^{0.6}}{0.9^{0.6} \cdot(35+0.1)^{0.4} \cdot 5.2^{0.4} \cdot 0.3^{0.2} \cdot\left(1,45 \cdot 10^{-5}\right)^{0.2}}=0,93 \text { мкM }
\end{aligned}
$$

Інтенсивність знімання металу $[6,7,15]$ :

$$
V_{m}=\frac{0,02 \cdot t \cdot V_{u} \cdot F_{3 a z}}{B}=\frac{0.02 \cdot 5.24 \cdot 10^{-6} \cdot 0.1 \cdot 8 \cdot 10^{-3}}{12}=6.987 \cdot 10^{-8} \mathrm{M}^{3} / \mathrm{c}
$$

Контактна температура $[4,5]$ :

$$
\begin{aligned}
& T=2.04 \cdot A \cdot\left[\frac{\operatorname{tg} \cdot m \cdot V_{u} \cdot t^{3.5} \cdot(1+\eta) \cdot V_{k} \cdot\left(1+\frac{l_{2}}{l_{1}}\right)^{3}}{\lambda^{2} \cdot C^{2} \cdot \rho_{g}^{2} \cdot \bar{x}^{2} \cdot(1-\eta)^{2}}\right]^{0.25}= \\
& =2.04 \cdot 17.1 \cdot\left[\frac{1 \cdot 0.5 \cdot 0.1 \cdot\left(0.05 \cdot 10^{-3}\right)^{3.5} \cdot(1+0.3) \cdot 35 \cdot\left(1+\frac{25.5}{40}\right)^{3}}{16.7^{2} \cdot\left(5.57 \cdot 10^{-8}\right)^{2} \cdot 99.998^{2} \cdot\left(40 \cdot 10^{-6}\right)^{2} \cdot(1-0.3)^{3}}\right]^{0.25}=209.34 \square
\end{aligned}
$$

Розмір лінійного зносу максимально виступаючого зерна [4]:

$$
\begin{aligned}
& X=\sqrt[3]{\frac{1444.4 \cdot V_{u} \cdot\left(1+\frac{l_{2}}{l_{1}}\right) \cdot \sqrt{\frac{2 t}{R} \cdot \bar{x}^{3} \cdot \eta^{3}}}{m \cdot V_{k} \cdot \operatorname{tg} \gamma \cdot\left(1-\eta^{2}\right)}}= \\
& =\sqrt[3]{\frac{1444.4 \cdot 0.1\left(1+\frac{0.0255}{0.04}\right) \cdot \sqrt{\frac{2 \cdot 0.05 \cdot 10^{-3}}{0.125} \cdot\left(40 \cdot 10^{-6}\right) \cdot 0.3^{3}}}{0.5 \cdot 35 \cdot 1 \cdot\left(1-0.3^{2}\right)}}=8.98 \cdot \mathrm{MKM} / \mathrm{Miн}
\end{aligned}
$$

Виконані розрахунки демонструють, що в рівних умовах абразивний круг 3 переривчастою робочою поверхнею порівняно 3 кругом із суцільною робочою поверхнею зменшує температуру в зоні контакту $\left(\Delta \mathrm{T}_{\text {жисх }}=-30 \%\right)$ при зміні інтенсивності знімання металу $0,8-8,98^{*} \cdot 10^{-8} \mathbf{M}^{3} / c$, що дає змогу збільшення продуктивності обробки приблизно на $40-$ $50 \%$. В цьому випадку деяке зростання шорсткості і швидкості розмірного зносу при шліфуванні кругом 3 переривчастою робочою поверхнею можна пояснити тим, що в умовах більш інтенсивного самозаточування зменшується кількість зерен на одиниці робочої поверхні круга 3 переривчастою робочою поверхнею, а також зменшується розмір площадок зносу на їх вершинах, що призводить до збільшення глибини проникнення абразивних зерен в метал. Однак, при цьому умови мікрорізання абразивними зернами покращуються, вимагаючи на знімання металу в одиницю часу менших енергетичних затрат, а зменшення висоти шорсткості при необхідності досягається відповідним зменшенням зернистості і збільшенням твердості круга, а також досягається зниження розмірного зносу. При цьому переривчаста робоча поверхня абразивного інструменту дозволяє вести обробку в області допустимих контактних температур. Зниження теплонапруженності при шліфуванні такими кругами дає можливість інтенсифікувати режими обробки без небезпеки виникнення припалів на оброблюваних поверхнях.

Порівняння можливостей, та перевірка експлуатаційних показників шліфувального круга 3 переривчастою робочою поверхнею і шліфувального круга з суцільною робочою поверхнею наведені на рис. 2 та 3. Дані результати порівняльного дослідження фізико-механічного стану поверхневого шару обробленої кругами з переривчастою робочою поверхнею та з суцільною робочою поверхнею показали, що в тонкому поверхневому шарі збільшується мікротвердість (рис. 3 , а) і з'являються залишкові напруження стиснення (рис. 3, б). Особливістю змін фізико механічних властивостей по глибині $є$ відсутність шару зі зниженою мікротвердістю. При шліфуванні звичайними кругами його поява обумовлена структурними перетвореннями, що виникають при високих температурах в зоні контакту. При шліфуванні кругами 3 переривчастою робочою поверхнею зменшується час контакту перетину поверхні 3 інструментом до $(1,6-3,5) \cdot 10^{-4} \mathrm{c}$, швидкість нагріву і охолодження поверхневого шару до 
$(2,1 \ldots 3.6) \cdot 10^{6} \circ \mathrm{C} /$ с. При таких швидкостях термічних процесів виникнення відпущеного шару малоймовірно.
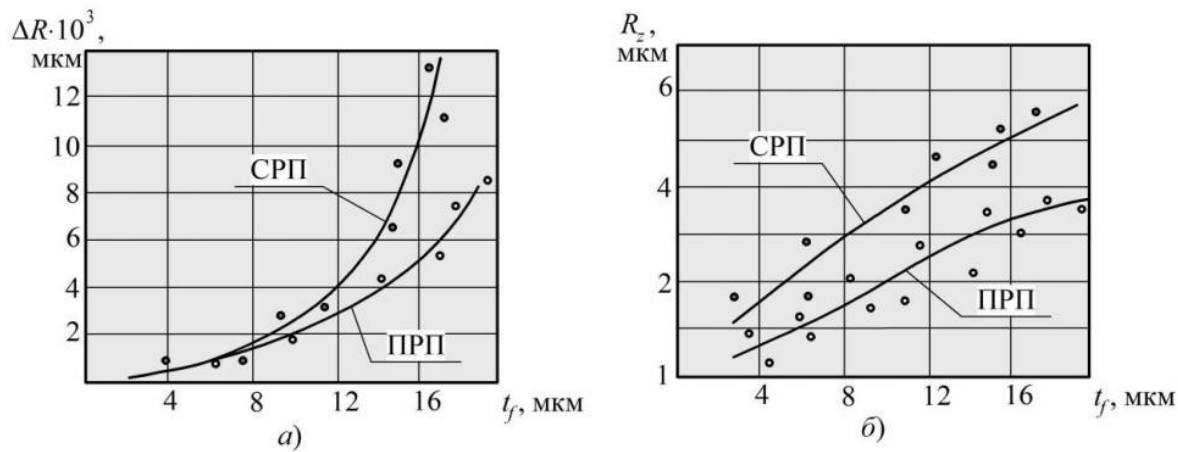

Рис. 2. Перевірка зносу шліфувального круга (a) і шорсткості оброблювальної поверхні (б) для кругів з суцільною робочою поверхнею (СРП) та переривчастою робочою поверхнею (ПРП).

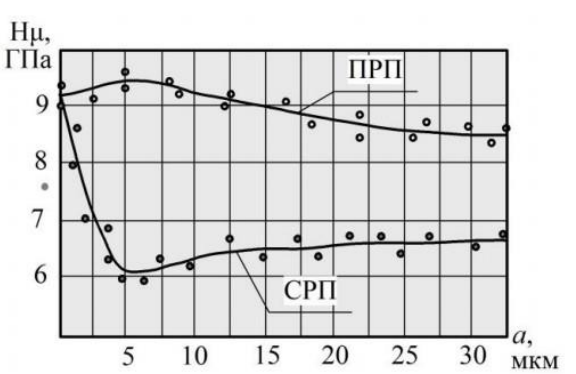

a)

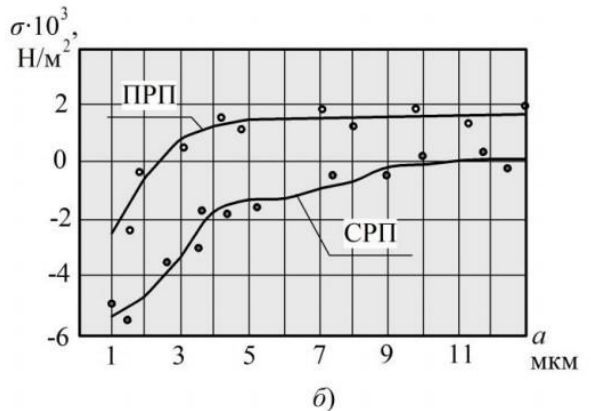

б)

Рис. 3. Розподілення мікротвердості ( $a$ ) і залишкових напружень (б) в поверхневих шарах зразків.

Висновок. Після проведення теоретичних досліджень, та порівнянь отриманих результатів можна зробити висновок про доцільність застосування на операціях безцентрового шліфування шліфувальних кругів з переривчастим профілем. При проектуванні безцентрових шліфувальних операції технологу з метою забезпечення заданої якості поверхневого шару оброблюваної поверхні та збільшення швидкості виготовлення продукції, слід попередньо вивчити методику розрахунків і потім виконати розрахунок геометричних параметрів переривчастого профілю круга, також провести розрахунок режимів високопродуктивного шліфування. А також враховувати особливості динаміки процесу шліфування. Для технологічної підготовки шліфувальних операцій важливим є розробка методики моделювання динамічних процесів з метою прогнозування впливу динаміки шліфування на показники якості шліфованих поверхонь.

\section{Інформаційні джерела}

1. Якимов, А. В. Прерывистое шлифование / А. В. Якимов. - К.: Вища школа, 1986. -175 с

2. Лищенко, Н. В. Температура при шлифовании прерывистыми и высокопористыми кругами / Н. В. Лищенко, В. П. Ларшин // Вектор науки ТГУ. - 2015. - № 3-1.- С. 75-84.

3. Якімов О.В., Марчук В.І., Лінчевський П.А., Якімов О.О., Ларшин В.П. Технологія машинота приладобудування: Підручник. - Луцьк: РВВ ЛДТУ, 2005. - 712 с.

4. Марчук B.I., Марчук I.В, Гринюк С.В., Сачковська Л.О. Моделювання процесу безцентрового шліфування робочих поверхонь кілець роликопідшипників в умовах серійного виробництва // Наукові нотатки: Міжвузівський збірник (за галузями знань «Технічні науки») - Луцьк: Луцький НТУ, 2019. Вип. 66. - С. 234-239

5. Марчук B.I., Гринюк С.В., Марчук I.В., Сачковська Л.О. Динамічна модель процесу шліфування переривчастими кругами // Збірник наукових праць «Перспективні технології та прилади». - Луцьк: Луцький НТУ, 2020. - №16. - C.33-37 DOI: https://doi.org/10.36910/67752313-5352-2020-16-5

6. Т.Г Джугурян, В.І Марчук, І.В Марчук, М.В Олексин, Л.О. Сачковська. До визначення умов зниження температури безцентрового шліфування переривчастими кругами. Перспективні технології та прилади 2018 р.№13, ст.48-52. 
7. Марчук В.I. Технологічні основи забезпечення якості робочих поверхонь кілець роликопідшипників [Текст] : дис... д-ра техн. Наук: 05.02.08 / Марчук Віктор Іванович ; Луцький держ. Технічний ун-т. - Луцьк, 2004. - 458 арк.+ дод.: 150арк. - арк. 430-458.

8. Марчук B.I. Класифікація та походження температурних дефектів на операціях безцентрового шліфування поверхонь обертання / Марчук, І.В. Марчук, М.В. Олексин, А.М. Ештеіві / Матеріали Шістнадцятої міжнародної молодіжної науково-технічної конференції «Машинобудування очима молодих: прогресивні ідеї-наука-виробництво», м. Суми, 26-29 жовтня 2016 р. - Суми: Сумський державний університет, 2016. - С. 102-103.

9. Джугурян Т.Г. Марчук І.В. Технологічне забезпечення точності та якості поверхонь обертання в підшипниковому виробництві/ «Перспективні технології та прилади». Збірник наукових праць. - Луцьк: ЛНТУ, 2017. - Випуск №12(1). - С. 111-119.

10. Марчук I.В., Марчук В.І., Модель стабілізації високочастотних коливних процесів в динамічній системі круглого врізного шліфування. Збірник наукових праць. - Луцьк: ЛНТУ, 2016. - Перспективні технології та прилади №9. - С.75-83.

11. Марчук І.В. Керування температурою на безцентрово-шліфувальних операціях / М.В. Олексин, А.М. Ештеіві // “Перспективні технології та прилади". Збірник наукових праць. Випуск 10(1). м. Луцьк, червень 2017 р. - Луцьк: Луцький НТУ, 2017. - С. 133-138.

12. Марчук І.В. Технологічне керування температурою під час безцентрового шліфування функціональних поверхонь обертання/ Марчук В.І. // «Наукові нотатки». Випуск 61. м. Луцьк, 2018 - Луцьк: Луцький НТУ, 2018. - С. 142-147

13. Марчук I.В. Технологічне забезпечення точності шліфування поверхонь обертання підшипників / І.В. Марчук, А.М. Ештеіві, М.В. Олексин / Наукові нотатки: Міжвуз. зб. Луцького національного технічного університету (за напрямком "Інженерна механіка"). Вип. 57. - Луцьк: Луцький НТУ, 2017. - С. 123-127.

14. Марчук I.В. Технологічне керування точністю поверхонь обертання на операціях механічного оброблення / І.В. Марчук, М.В. Олексин, А.М. Ештеіві / «Сучасні технології у промисловому виробництві»: матеріали науково-технічної конференції викладачів, співробітників, аспірантів і студентів факультету технічних систем та енергоефективних технологій (м. Суми, 18-21 квітня 2017 р.): у двох частинах / редкол.: О. Г. Гусак, В. Г. Євтухов. - Суми: Сумський державний університет, 2017. - Ч. 1. - 31-32 с.

15. Марчук І.В. Технологічне керування точністю поверхонь обертання в умовах переналагоджувального підшипникового виробництва / І.В. Марчук, А.М. Ештеіві / Збірник тез доповідей XVI-ї Міжнародної науково-технічної конференції «ПРИЛАДОБУДУВАННЯ: стан і перспективи», ПБФ, КПІ ім. Ігоря Сікорського, 16-17 травня 2017 р., м. Київ, Україна. - 2017. C. 83

16. Марчук B.I. До аналізу джерел та причин походження вібрацій в конічних роликопідшипниках / B.I. Марчук, I.В. Марчук, А.М. Ештеіві, М.В. Олексин / Наукові нотатки: Міжвуз. зб. Луцького національного технічного університету (за напрямком "Інженерна механіка"). Вип. 59. - Луцьк: Луцький НТУ, 2017. - С. 184-192.

\footnotetext{
${ }^{1}$ Marchuk V.I., ${ }^{1}$ Marchuk I.V., ${ }^{2}$ Dzhuguryan T.G., ${ }^{1}$ Karpyuk V.O.

${ }^{1}$ Lutsk National Technical University, Lutsk, Ukraine

${ }^{2}$ Szczecin Maritime Academy, Poland
}

\section{ON THE EXPEDIENCY OF APPLICATION OF GRINDING WHEELS WITH A BROKEN PROFILE IN OPERATIONS OF CENTER-FREE GRINDING OF ROTARY SURFACES}

The comparative analysis of the work of grinding wheels with a continuous and intermittent working surface for finishing abrasive treatment of the surfaces of roller bearing rings is made in the work. For the finishing abrasive treatment of the surfaces of the roller bearing rings, it is shown that the results of the expected contact temperature, roughness and wear intensity at a given intensity of metal removal are confirmed by theoretical calculations. The obtained results allow us to conclude that in centerless grinding operations, especially when machining roller bearing rings, it is advisable to use grinding wheels with an intermittent surface.

Key words: grinding wheel, abrasive tool, centerless grinding, intermittent profile, dimensional wear, temperature in the cutting zone, surface of rotation. 